\title{
DETERMINANT OF THE CORPORATE ENVIRONMENTAL DISCLOSURE: STUDY ON JAKARTA ISLAMIC INDEX
}

\author{
Yulianti, Leis Suzanawaty, Zuwesty Eka Putri, Ismawati Haribowo
}

\begin{abstract}
Determinant of The Corporate Environmental Disclosure: Study on Jakarta Islamic Index. The issue about corporate environment disclosure nowadays is increasing. This research aims to analyze the influence of firm size, leverage, proportion of independent commissioners, corporate secretary and firm age to corporate environmental disclosure. Thirteen companies that listed at Jakarta Islamic Index during 2011-2014 are used as sample. Data was analyzed using multiple regression technique. The independent variables are firm size, leverage, and proportions of independent commissioners, corporate secretary, and firma age. The result shows that simultaneously all independent variables have significant influence to corporate environmental disclosure. Whereas partially, firm size and firm age have significantly influence to corporate environmental disclosure. The implication of this research is the larger of the firm size and the longer firm will make a better corporate environmental disclosure in companies that listed at Jakarta Islamic Index.
\end{abstract}

Keywords: corporate environmental disclosure; corporate secretary; firm age; firm size; leverage; proportion of independent commissioner

\begin{abstract}
Abstrak. Determinan atas Pengungkapan Lingkungan Perusabaan: Studi Pada Jakarta Islamic Index. Isu mengenai pengungkapan lingkungan perusahaan saat ini cukup mengemuka. Penelitian ini bertujuan untuk menganalisis pengaruh ukuran perusahaan, leverage, proporsi komisaris independen, sekretaris perusahaan dan umur perusahaan terhadap pengungkapan lingkungan perusahaan. Tiga belas perusahaan yang terdaftar di Jakarta Islamic Index selama 2011-2014 itu digunakan sebagai sampel. Data dianalisis menggunakan teknik regresi. Variabel independen yang dipergunakan ialah ukuran perusahaan, leverage, proporsi komisaris independen, sekretaris perusahaan, dan umurperusahaan. Hasil pengujian menunjukkan bahwa secara simultan semua variabel independen berpengaruh signifikan terhadap pengungkapan lingkungan perusahaan. Sedangkan, ukuran sebagian hanya perusahaan dan umur perusahaan berpengaruh signifikan terhadap pengungkapan lingkungan perusahaan. Implikasi penelitian ini ialah semakin besar ukuran perusahaan dan semakin lama umur perusahaan akan mengakibatkan semakin baiknya pengungkapan lingkungan perusahaan pada perusahaan yang tercatat di Jakarta Islamic Indeks (JII).
\end{abstract}

Kata kunci: pengungkapan lingkungan perusahaan; sekretaris perusahaan; umur perusahaan; ukuran perusahaan; proporsi komisaris independen 


\section{Introduction}

Nowadays there is a variety of environmental damage as a result of human activities. On the beach on the Island of Bangka-Belitung, there was contamination of seawater and open waters; the land becomes barren, coastal erosion and sea damage. This was the result of unconventional tin mining activities (Ambadar, 2008). Another example is the conflict between PT. Freeport Indonesia with the people of Papua. Land use of indigenous lands, destruction and damage of the environment, the destruction of the economy, and disavowal of the existence of Amungme population is the harsh reality that must be accepted by the people of Papua due to the presence of mining operations of PT. Freeport Indonesia. Disaster of damage to the environment and other communities arising is the collapse of Wanagon Lake up to three times (June 20, 1998; March 20-21, 2000; May 4, 2000) due to the waste disposal in the enormous capacity and incompatible with the carrying capacity of environment (Rudito and Famiola, 2007). Another case is the case of hot mud in Sidoarjo caused by the negligence of PT Lapindo Brantas, the case of Oil and Natural Gas Mining Company, Unicoal (US company), the case of PT Kelian Equatorial Mining in the Dayak community, the case of Dayak tribes with the Australian-owned gold mining company (Aurora Gold), and the case of mercury pollution that threatens the lives of 1.8 million people of Central Kalimantan, which is the case of Dayak tribes vs "Minamata". Meanwhile, the petroleum industry also contributed to the pollution that occurred on the land and sea. There are at least 6,500 oil platforms located in the Gulf of Mexico and spread along the shore of the oil-producing countries. On the other hand, there are a plenty of oil pipes buried in the ground for the benefit of product distribution. All of this contributes to the increase of environmental risks as a result of the incident that caused the environmental disaster oil. The explosion in one of the oil platforms resulting in leakage of crude oils that polluting the Gulf of Mexico in 2010 (Eljayash et.al, 2012).

A variety of problems faced by the earth as described above make the saving the earth becoming increasingly important (Rahbar, 2011). In the perspective of Islam, this task becomes the responsibility of human beings as a vicegerent of Allah on earth (Abu Hola, 2009). Rehman and Dost (2013) stated that the problems faced by this earth, it is undeniable that it was also a result of the corporate activities (Rehman and Dost, 2013). Meanwhile, society's expectations to the company have changed over the last two decades. Complex business environment requires companies to balance the demands of various stakeholders and executives (Da Rosa, 2012). Stakeholders give strong pressure on companies to demonstrate responsibility towards the environment. Environmental disclosure issues became important for 
investors, policy makers, and the general public (Juhmani, 2014). These conditions, in turn, would encourage companies perform environmental disclosure (Akrout and Othman, 2013; Galani et.al, 2011). In terms of quantity, the number has increased every year (Hossain et.al, 2016). Makori and Jangogo (2013) state that the increase in quantity has been encouraged by the awareness on the benefits from the existence of reporting on environmental issues.

Juhmani (2014) stated that companies that have the most active role in the economy, should not only pay attention to economic issues only, but also need to demonstrate social and environmental responsibility through internal and external reporting. Meng et.al (2011) stated that companies that demonstrate poor environmental performance would be facing political and social pressures that threaten their legitimacy. The Company is actively responding to pressure from the government and complies with government regulations to gain legitimacy.

Concern about the impact which caused by the business on communities has been encouraging scientific research in various fields (Rosa et.al, 2012). Research on the social and environmental accounting is widely promoted in 1970, then disappeared in 1980, and then came back starting in mid of 1990 (Battacharyya and Stanton, 2007). Various studies have been conducted to reveal the antecedents of corporate environmental disclosure, such as: profitability, leverage, family ownership, as well as the size, characteristics and performance of the company (Akrout and Othman, 2013; Elsakit and Worthington, 2014; Ali and Rizwan, 2013). This issue has become an important topic in studies conducted in various countries (Galani, et.al, 2011).

Hossain et.al (2006) stated that most research on corporate environmental disclosure, carried out in developed countries, such as European and United States countries. Instead, the research is still rare in developing countries, including Indonesia. The concept of environmental disclosure is not universally applicable concept in each country because of the different stages of economic development, enterprise awareness and attitudes towards corporate environmental disclosure. Research in Indonesia, especially on companies listed in the Jakarta Islamic Index is still very limited. Likewise, the type of industry, which became the research objects. In previous research, the industry that made as the research objects are mining, food, chemical, energy, transportation and pharmaceuticals. In addition to these objects, there are still companies in other areas that potentially cause pollution. Therefore, in this study, the research object was expanded by adding the agricultural (Dressage, 2004 in Almilia and Vitello 2007). In addition to the expansion of the research object and location differences, this research also revealed other antecedents that have not been tested empirically by previous research. The antecedent is the 
corporate secretary. Surya and Yustiavanda (2008) stated that the existence of corporate secretary has an important role in environmental disclosure because it is the party whom holds the data and reports that are material nature.

\section{Literature Review}

Agency theory is a theory that discusses about the problem of separation between ownership and management of the Company. It is what lies behind the emergence of good corporate governance. Jensen and Mecling (1976) defines an agency relationship as a contract between one or more person (the principal) who hired (agent) to perform services for the benefit of the principals in managing their wealth that involves granting rights to decision-making to the agent. In broad outline Jensen and Mecling (1976) describes two types of agency relationshipsthat is between managers and shareholders and between managers and lenders (bondholders).

Agency theory according to Jensen and Meckling (1976) has the assumption that both parties are equally want to maximize profits, so sometimes the agent is not doing its best in the interest of the principal. So that it could cause conflicts of interest between both parties. Efforts to solve the agency conflict would cause agency costs that would be borne either by the principal or agent. Jensen and Meckling (1976) divide the cost of agency into three, namely: (1) Monitoring costs, is costs borne by the principal to monitor the agent, which is to measure, observe and control the behavior of agents. For example audit fees, compensation cost for managers; (2) Bonding cost, is costs borne by the agents to determine and comply with mechanisms to ensure that the agent will act for the interest of the principal. Such as the costs incurred by the Manager to provide financial statements to shareholders; (3) Residual loss, is loss suffered by the owner due to irregularities on actions that escaped from surveillance such as excessive spending and unnecessarily from the agent. An understanding from such context that if that good corporate governance applied properly then the agency costs could be minimized so that profit which is a measure of financial performance would increase.

Stakeholder theory provides a framework for analysis of the relevant stakeholders in giving pressure for companies to conduct environmental disclosure. According to the stakeholder theory, environmental information disclosure is the result from the external pressure, especially from the government and community (Meng et.al, 2013).

Stakeholder theory concept emphasizes the importance of management to coordinate with all parties involved in the company. Management is required to 
perform balance of interests, whether between shareholders and stakeholders and inter stakeholders. This is to avoid any conflict of interest among them (Daniri, 2005).

Firm size may be expressed in total assets, sales and market capitalization. The greater the total assets, sales and market capitalization, the greater the firm size. These three variables are used to determine the firm size because it could represent how big the company. The greater the assets, the more capital are invested. The more sales, the more the velocity of money and the bigger the market capitalization, the greater it is known in the community. From these three variables, the value of assets is relatively more stable than the market value of capitalize and sales in measuring the firm size (Sudarmadji and Sularto, 2007).

Managers from the big companies realize the positive benefits from the environmental disclosure, while managers of small companies consider disclosure could jeopardize their position in competing (Rouf, 2011). According to the agency theory, social responsibility disclosure, including environmental disclosure, may reduce the political costs that could reduce corporate welfare. The political cost would be higher in line with the increase in the firm size (Hossain et.al, 2006). Hossain, et. $\mathrm{Al}$ (2006) stated that there is positive relationship between firm size and the level of environmental disclosure in the annual report, both in developed countries and developing countries. It is also disclosed by Qiu et.al. In his opinion, big companies listed on the exchange would be more revealing information about the environment with better quality.

Leverage used to describe the ability of companies to use the assets or funds that have a fixed load (fixed cost assets or funds) to increase earnings (return) to the company owners (Isaskar, 2012). In this research leverage proxied by using the debt to equity ratio (Juhmani, 2014). Board of Commissioners in charge of overseeing the policy and implementation of policies by the board of directors, and provide advice to the board of directors. Details of these tasks are usually described in the articles of association of the company. Policies that are a concern the Board of Commissioners are policies that important and strategic (Muntoro, 2006). From the perspective of the Agency Theory, the capabilities of the board of commissioners to perform effective monitoring is affected by the independence or impartiality in management. Various studies have shown the positive effect by placing the autonomous external director on the Board of Directors (Leong et.al, 2015). To encourage management of the company to be better and improving the protection for creditors, additional organs in the company urgently needed. According to the legitimacy theory, social existence of companies affected by the public reception where the company operates. Companies that operate much longer are more need a communication 
with the outside community. Therefore the company would disclose social and environmental information (Juhmani, 2014). In this research using the proportion of independent commissioners with a total commissioners (Effendi et.al, 2012)

This profession of corporate secretary is different from the executive secretary profession who became the secretary of director, commissioner or other executives at the company. This difference is due to the corporate secretary should have access to material information that is relevant to the issue of disclosure (Surya and Yustiavanda, 2008). Based on these descriptions, researchers speculate that the corporate secretary has an influence on corporate environmental disclosure. In this research using the total of the days reporting as indicators of corporate secretary variable.

According to the legitimacy theory, social existence of companies is affected by the public reception where the company operates. Companies that operate much longer are more need a communication with the outside community. Therefore the company would disclose social and environmental information (Juhmani, 2014).

Environmental disclosure is part of the social reporting and non-financial nature (Makori and Jangongo, 2013). Environmental disclosure is a process of delivering the environmental impact caused by the company activities, and the settlement of these problems. Delivery of the report is a form of corporate accountability to the public, as well as is the method used to reveal the environmental responsibility to the stakeholders (Da Rosa, 2012). Disclosure of information about the environment is voluntary, and arranged through corporate policies (Rouf, 2011). A number of companies choose to publish environmental disclosure, while some choose not to disclose such information (Lyon and Maxwell, 2011). Environmental disclosure conducted by the company because of the need to present the company activities at all times through reports, websites, and other documents. Environmental disclosure shows the company commitment towards the environment (Stray, 2008).

Environmental disclosure is one of impression management, which is part of the social reporting. The Company may disclose information in a selective manner (Hossain et.al, 2006; Meng et.al, 2013). Therefore, the content of environmental disclosure varies from company with another company (Galani, et.al, 2011). This is influenced by the attitude changes that occur in society, economic and behavioral factors, such as corporate culture (Rouf, 2011). To determine the level of disclosure, are used unweight disclosure index. Unweight disclosure index is the ratio between items disclosed divided by the total item value that could be disclosed. In the calculation of this index, all items of information are considered equally important. Unweight environmental disclosure index assumes every item as a dichotomous variable by using the financial statements as a source of information, researchers (Hossain et.al, 2006). 
Effendi et.al (2012) in his research on the influence of commissioners to the environmental disclosure in manufacture company which listing on the Stock Exchange in 2008-2011 with the research results that the commissioners size, proportion of Independent Commissioners, the commissioner president educational background could not be proven to have an influence on environmental disclosure. Commissioners are not affecting the environmental disclosure because the Board of Commissioners does not have any interest to the environmental disclosure. Control variables that influence are the size and leverage.

According to the research of Galani et.al (2012), the firm size that proxied by sales and profitability had an influence on corporate environmental disclosure. Meanwhile, according to Eljayash et.al (2012) environmental disclosure practices varies in different countries. Among the companies that were sampled, researchers found a significant gap. Akrout and Othman (2013) concluded that the ownership structure which proxied by family ownership has a negative influence. Firm size and profitability has a significant influence on the Corporate Environmental Disclosure. The research of Elsakit and Warthington (2014) concluded that the Environmental Disclosure is influenced by the Corporate Governance and company characteristics (profitability, ownership, firm size and listing on the stock exchange). And the research of Juhmani (2014) concluded that Leverage and audit firm size has an influence on environmental disclosure.

\section{Methods}

Research could be classified into quantitative and qualitative. Both have different characteristics and may be used either separately or simultaneously. This research is quantitative research. Quantitative research conducted to explain the causes of a change through objective measurement and quantitative analysis (statistical) (Wahyuni, 2011). This technique focused on the collection of numerical data and carry out generalization in the various groups or people to explain certain phenomena (Babbie, 2010).

Research could use secondary data or primary data. Primary data is data generated by researchers for the specific purpose to solve the problems encountered. Meanwhile secondary data is data that has been collected by other party. Secondary data collection conducted with the aim that could be different from the goal of researchers. Secondary data can be obtained easily and inexpensively. Secondary data can be obtained from internal sources and external sources. Internal secondary data sourced from within the company. While the external secondary data can be obtained from: government, syndication corporate, trade associations, and other sources (Malholtra, 2010). 
This research use secondary data that sourced from Jakarta Islamic Index. Data used in the form of company documentation, such as financial statements. Data obtained from the Indonesia Stock Exchange, etc. Sample determination may be conducted with technique of probability or non-probability sampling. Probability sampling is a sampling technique in which all members of the population has a probability to be sample, or in other words, the probability to become members of the sample is not zero (nonzero probability). This research use judgment sampling where these criteria are companies engaged in the mining, food, chemical, energy, telecommunications, transportation real estate, pharmaceuticals and agriculture registered since 2011 until 2014.

Data, which obtained were analyzed using multiple regression techniques with classic assumption test and significance tests. Multiple regression technique is an extension of the simple regression. This technique is used to predict a metrics dependent variable by total independent variables (Zikmund et.al, 2010). In general, the regression equation could be written as follows (Levine et.al, 2005; Alhusin, 2003)

$Y=\alpha+\beta_{1} X_{1}+\beta_{2} X_{2}+\beta_{3} X_{3}+\beta_{4} X_{4}+\beta_{5} X_{5}+\varepsilon$

Where:

Y : Corporate Environmental Disclosure

$\mathrm{X}_{1}$ : Firm Size

$\mathrm{X}_{2}$ : Leverage

$\mathrm{X}_{3}$ : Proportion of Independent Commissioners

$\mathrm{X}_{4}$ : Corporate Secretary

$\mathrm{X}_{5}$ : Firm Age

\section{Result and Discussion}

Normality test using the histogram and normal P-Plot resulted in the conclusion of normal data distribution. Whereas statistical tests using the Kolmogorov Smirnov Test obtained a significant value of 0.2000 so that the significant value $>0.05$, meaning that the data distribution is normal. In multicollinearity test obtained a VIF $<10$ and Tolerance $>0.1$. It can be concluded there are no symptoms of multicollinearity among variables. Autocorrelation test by using Durbin Watson test where the value $d=1.734$. The value is in between the value of $d u$ and 4-du where the value of $d$-count is greater than (du) 1.3512 and less than (4-du) 2.2306 so it could be concluded that the data did not contain autocorrelation symptoms. Whereas the heterocedastisity test using a scatterplot graph could be concluded if 
no symptoms of heterocedastisity because in the scatterplot graph seen that the dots randomly spread and spread both above and below the number 0 on the Y-axis.

Table 1 Determination Coefficient Results Model Summary-b

\begin{tabular}{lccccc}
\hline Model & R & R Square & $\begin{array}{c}\text { Adjusted R } \\
\text { Square }\end{array}$ & $\begin{array}{c}\text { Std. Error of } \\
\text { the Estimate }\end{array}$ & $\begin{array}{c}\text { Durbin- } \\
\text { Watson }\end{array}$ \\
\hline 1 & $.592^{\mathrm{a}}$ & .350 & .279 & .27067 & 1.734 \\
\hline $\begin{array}{l}\text { a. Predictors: (Constant), Firm age, Proportion of Commissioners, Firm Size, leverage, corporate } \\
\text { secretary }\end{array}$ & & & & \\
b. Dependent Variable: CED & & & & \\
\hline
\end{tabular}

Source: SPSS Output processed

In this research, testing of determination coefficient $\left(\mathrm{R}^{2}\right)$ was conducted to measure the independent variables namely variables Board of Commissioners meetings, corporate secretary in explaining the variation of dependent variables, corporate environmental disclosure. Determination coefficient test results can be seen in Table 1.

Table 1 showed that the value of $\mathrm{R}$ Square amounted to 0.350 . This means that at $35 \%$ of the dependent variable or corporate environmental disclosure is influenced by independent variables are firm size, leverage, proportion of Independent Commissioners, corporate secretary and firm age while the remaining at $65 \%$ is explained by other factors that are not included in this research such as business culture, internet penetration, profitability, industry type, multinational company (Akrout and Othman, 2013), (Galani, 2011), (Hossain, et.al, 2006), (Elsakti and Worthington, 2014).

The hypothesis testing in this research was conducted by using multiple regression analysis models. According Ghozali (2013) multiple regressions is used to test the effect of more than one independent variable on one dependent variable. In this research, hypothesis testing was conducted by simultaneous significance test ( $F$ statistical test) and individual parameter significance test ( $\mathrm{t}$ statistical test).

Simultaneous significance test (F statistical test) is conducted to test whether all the independent variables in the regression equation model have simultaneously effect on the dependent variable. Simultaneous significance test (F statistical test) was conducted at the significance level of 0.05 . If the $\mathrm{F}$ probability value is greater than 0.05 then $\mathrm{H} 0$ is accepted and $\mathrm{Ha}$ rejected, otherwise if the $\mathrm{F}$ probability value smaller than 0.05 then $\mathrm{H} 0$ rejected and $\mathrm{Ha}$ accepted. Table 2 presents the results of simultaneous test (F statistical test). 
Table 2 Simultaneous Tests

ANOVA $^{a}$

\begin{tabular}{ccccccc}
\hline \multirow{2}{*}{ Model } & & $\begin{array}{c}\text { Sum of } \\
\text { Squares }\end{array}$ & df & $\begin{array}{c}\text { Mean } \\
\text { Square }\end{array}$ & F & Sig. \\
\hline \multirow{2}{*}{1} & Regression & 1.814 & 5 & .363 & 4.951 & $.001^{\mathrm{b}}$ \\
& Residual & 3.370 & 46 & .073 & & \\
& Total & 5.184 & 51 & & & \\
\hline
\end{tabular}

a. Dependent Variable: CED

b. Predictors: (Constant), Firm age, Proportion of Commissioners, Firm Size, leverage, corporate secretary

Source: SPSS Output processed

Based on Table 2 regarding the simultaneous test table (F statistical test) or ANOVA test showed that the value of F-count of 4.951 with a probability of 0.001 . Because the probability of 0.001 smaller than 0.05 , then this regression equation model could be concluded that all the independent variables namely firm age, Proportion of Commissioners, Firm Size, leverage, and corporate secretary have a simultaneously effect on the corporate environmental disclosure.

Partial testing or $\mathrm{t}$ test is used to show how far the influence of one independent variable individually in explaining the variation of dependent variable that tested at a significance level of 0.05 . T test results shown in Table 3 .

Based on the Table 3, showed that the coefficient of regression model has constant value amounted to -4.106 . The constant of -4.106 indicates that if the independent variables constant then the average of corporate environmental disclosure amounted to -4.106 . The variable firm size (size) has t-count positive at 4.257 with a significance level of 0.000 . It showed that significance level is above 0.05 . Then could be concluded that the firm size, which is proxies by sales, has an effect on the corporate environmental disclosure. The t test results for the leverage variable have $t$-count negative of -1.485 with a significance level of 0.144 . It showed that the significance level is above 0.05 . Therefore the leverage has no effect on the corporate environmental disclosure. The Proportion of Independent Commissioners have $t$-count negative of -0.772 with a significance level of 0.144 . It showed that the significance level is above 0.05. Therefore the Proportion of Independent Commissioners has no effect on the corporate environmental disclosure. 
Table 3 t-Test Results

Coefficients $^{a}$

\begin{tabular}{lccccccc}
\hline & \multicolumn{2}{c}{$\begin{array}{c}\text { Unstandardized } \\
\text { Model }\end{array}$} & Coefficients & $\begin{array}{c}\text { Standardized } \\
\text { Coefficients }\end{array}$ & $\mathrm{t}$ & Sig. & \multicolumn{2}{c}{$\begin{array}{c}\text { Sollinearity } \\
\text { Statistics }\end{array}$} \\
& $\mathrm{B}$ & Std. Error & Beta & & & Tolerance & VIF \\
\hline (Constant) & -4.106 & 1.173 & & -3.501 & .001 & & \\
Firm Size & .363 & .085 & .562 & 4.257 & .000 & .810 & 1.235 \\
Leverage & -.136 & .091 & -.203 & -1.485 & .144 & .755 & 1.325 \\
Commissioners & -.241 & .312 & -.107 & -.772 & .444 & .736 & 1.358 \\
Corp. Secretary & .000 & .003 & -.006 & -.042 & .967 & .743 & 1.346 \\
Firm Age & -.003 & .001 & -.255 & -1.990 & .053 & .863 & 1.159 \\
\hline a. Dependent Variable: CED & & & & & & \\
\hline
\end{tabular}

Source: SPSS Output processed

The corporate secretary have $\mathrm{t}$-count negative of -0.042 with a significance level of 0.967. It showed that the significance level is above 0.05 . Then could be concluded that the corporate secretary has no effect on the corporate environmental disclosure. The firm age have t-count negative of $-1,990$ with a significance level of 0.0537. It showed that the significance level is above 0.05 . Then could be concluded that the firm age has no effect on the corporate environmental disclosure on the alpha $5 \%$, but has an effect on the alpha of $10 \%$. Based on Table 3, the model of multiple regression equation is as follows:

$$
\mathrm{CED}=-4,106+0.363 \text { Size }-0,003 \text { Firm age }+\varepsilon
$$

The above results explainable that the constant value of -4.106 with a negative value, which means that corporate environmental disclosure would be valued at -4.106 if each variable of firm size and firm age valued at 0 . Regression coefficient value of firm size variable amounted to 0,363 . This indicates that if every $1 \%$ increase in the firm size variable, with the assumption that other variables are fixed then it would increase the corporate environmental disclosure by $36.3 \%$.

Regression coefficient value of firm age variable amounted to -0.003 . This indicates that if every $1 \%$ increase in the firm age variable, with the assumption that other variables are fixed then it would decrease the corporate environmental disclosure by $0.3 \%$. Based on the testing that was done, the results of this research showed that the variable of firm size (SIZE) which proxies by total sales have t-count amounted to 4.257 with a significance level of 0.000 is less than alpha of 0.05 . 
Therefore the first hypothesis (H1) was accepted, meaning that the firm size have an effect on corporate environmental disclosure. Unstandardized beta coefficient value amounting to 0.363 . It could be interpreted that firm size are big have an effect on corporate environmental disclosure

The tendency of big companies has more potential to disclose the environmental disclosure compared with small companies because: (1) the cost for information is very high, big companies have sufficient resources to undertake the cost of such information in the annual report, (2) the agency fee is higher for large companies because shareholders whose spread widely. More disclosure of company information would reduce the potential costs of agency (Walts \& Zimmerman, 1983), (3) big companies are more likely to disclose information in the annual report with the aim of competitive cost advantage (Lang \& Lundholm, 1993; Lobo \& Zhou, 2001) in Galani et. al (2011). The results of this research are consistent with the results of research conducted by Akrouth and Othman (2013). Galani et.al (2011), Hossain, et. al (2006) Elsakti and Worthington (2014). This research is inconsistent with Juhmani (2014).

The research result showed that the leverage variable have $t$-count of -1.485 with a significance level of 0.144 . It showed that the significance level is above 0.05 . Therefore the second hypothesis $(\mathrm{H} 2)$ was rejected, meaning that the leverage has no effect on corporate environmental disclosure. Companies that have high financial leverage would be more revealing information related to social and environmental when compared with companies that have a low financial leverage (Juhmani, 2014). It aims to attract investors. However another opinion stating that the companies that has a high leverage more likely close with infringement the agreement of existing debt and will be seen to have a high capital cost because many involve high-risk debt (Karim et.al, 2006) so that the high leverage level would be related to the reduction of environmental information disclosure (Cormier and Magnan, 1999). The result of this research is consistent with Meng.e.al (1999). The result of this research is not consistent with the research of Juhmani (2014), Akrouth and Othman (2013).

In proportion of independent commissioner variable, the result showed that $\mathrm{t}$-count amounted to -0.772 with a significance level of 0.444 . Therefore the third hypothesis $(\mathrm{H} 3)$ was rejected, meaning that the proportion of independent commissioner has no effect on corporate environmental disclosure. The proportion of independent commissioner does not affect the disclosure of environmental disclosure because the commissioners did not have any interest towards environmental disclosure (Effendi et.al.). The result of this research is consistent with the result of research conducted by Effendi et.al. Based on the testing was conducted, this research result showed that the corporate secretary variable have $\mathrm{t}$-count of -0.042 with a significance level of 0.967 . Therefore the fourth hypothesis 
(H4) was rejected, meaning that the corporate secretary has no effect on the corporate environmental disclosure. The result of this research is not consistent with Surya and Yustiavanda, (2008). Based on the testing was conducted, this research result showed that the firm age variable have $\mathrm{t}$-count of -1.990 with a significance level of 0.053 . . Therefore the fourth hypothesis (H4) was accepted at the alpha level of $10 \%$, meaning that the firm age has an effect on corporate environmental disclosure. Beta value indicates -0.003 . This may imply that the longer the firm age then the tendency to disclose the corporate environmental be decreased. The result of this research is not consistent with Juhmani (2014).

\section{Conclusions}

Based on the research analysis and discussion that has been presented in the previous chapters, the conclusions that obtained from this research are the firm size has an effect on the corporate environmental disclosure. The results of this research are consistent with the results of research conducted by Akrouth and Othman (2013). Galani et.al (2011), Hossain, et. al (2006) Elsakti and Worthington (2014). This research is not consistent with Juhmani (2014). Leverage Variable has no effect on the corporate environmental disclosure. The results of this research are consistent with Meng.e.al (1999). The results of this research are not consistent with the research of Juhmani (2014), Akrouth and Othman (2013). The proportion of independent commissioner has no effect on the corporate environmental disclosure. The results of this research are consistent with the results of research conducted by Effendi et al. Corporate secretary has no effect on the corporate environmental disclosure. The results of this research are inconsistent with Surya and Yustiavanda, (2008). Firm age has an effect on the corporate environmental disclosure. The results of this research are inconsistent with Juhmani (2014). The firm size, leverage, proportion of independent commissioner, corporate secretary and firm age are effect on the corporate environmental disclosure.

\section{References}

Akrout, M.M \& H.B. Othman. (2013). A Study of The Determinants of Corporate Environmental Disclosure in MENA Emerging Markets. Journal of Review on Global Economics. Vol. 2: 46-59.

Alhusin, S. (2003). Aplikasi Statistik Praktis dengan SPSS. Jakarta: Graha Ilmu.

Ali, W. \& M. Rizwan. (2013). Factors Influencing Corporate and Environmental Disclosure Practice in The Developing Countries: An Institutional Perspective. International Journal of Asian Social Science. Vol. 3: 590 -609. 
Almilia, L.S. \& D. Wijayanto. (2007). Pengaruh Environmental Performance dan Environmental Disclosure terhadap Economic Performance. The $1^{\text {st }}$ Accounting Conference, Depok, 7-9 November 2007

Ambadar. J. (2008). Corporate Responsibility dalam Praktik di Indonesia. Jakarta: Elex Media Computindo.

Ardi, M.S. \& L. Sularto. (2007). Pengaruh Ukuran Perusahaan, Profitabilitas, Leverage, dan Tipe Kepemilikan Perusahaan terhadap Luas Voulntary Disclosure Laporan Keuangan Tahunan. Proceeding PESAT (Psikologi, Ekonomi, Sastra, Arsitek dan Sipil). (2) , A53 - A61

Battarcharyya, A \& P. Stanton. (2007). Managerial Attitudes Toward Social and Environmental Accountability - Evidence from Indian Pharmaceutical and Biotech Industry. Accounting, Auditing and Accountability Journal. Vol 20 (3): 472-494.

Daniri, M.A. (2005). Good Corporate Governance: Konsep dan Penerapannya di Indonesia. Jakarta: Ray Indonesia.

Rodrigues. (2007). Issues in Corporate Social and Environmental Reporting Research: An Overview. Issues in Social and Environmental Accounting. Vol. 1 (1): 72-90.

Da Rosa, F.S et.al. (2012). Environmental Disclosure Management: a Constructivist Case. Management Decision. Vol. 50 (6): 1117-1136

Eljayash, K.M. et.al. (2012). The Quantity and Quality of Environmental Disclosure in Annual Reports of National Oil and Gas Companies in Middle East and North Africa. International Journal of Economics and Finance. Vol. 10: 201-2017.

Elsakit, O.M \& A.C. Worthington. (2014). The Impact of Corporate Characteristics and Corporate Governance on Corporate Social and Environmental Disclosure : A Literature Review. International Journal of Business and Management. Vol. 9: 1-16.

Galani, D. et.al. (2011). The Relation between Firm Size and Environmental Disclosure. International Conference on Applied Economics: 179-186.

Hair, J.H. et.al. (2010). Multivariate Data Analysis A Global Perspective $7^{\text {th }}$ ed. New Jersey: Pearson.

Jensen, M.C \& W.H. Meckling. (1976). Theory of the Firm: Management Behavior, Agency Cost and Ownership Structure. Journal of Finance Economic. Oktober. Vol. 3: 305-360

Juhmani, O. (2014). Determinants of Corporate Social and Environmental Disclosure on Website : The Case of Bahrain. Universal Journal of Accounting and Finance. Vol. 5: 77-86 
Li, W. \& R. Zhan. (2010). Corporate Social Responsibility, Ownership Structure, and Political Interference: Evidence from China. Journal of Business Ethics. Vol. 96: 631-645

Lyon, T.P. \& J.W. Maxwell. (2011). Greenwash: Corporate Environmental Disclosure under Threat of Audit. Journal of Economics \& Management Strategy. Vol 20 (1): 23-41

Makori. D.M \& A. Jagongo. (2013). Environmental Accounting and Firm Profitability: An Empirical Analysis of Selected Firms Listed in Bombay Stock Exchange, India. International Journal of Humanities and Social Science. Vol 3 (18): 248-256.

Malholtra. N.K. (2010). Marketing Research : An Aplied Orientation. New Jersey: Pearson

Meng, et.al. (2011). From Voluntarism to Regulation: A Study on Ownership, Economic Performance and Corporate Environmental Information Disclosure in China. Journal of Business Ethics. Issue. 116: 217-232

Pratama, A.G. \& Rahardja. (2013). Pengaruh Good Corporate Governance dan Kinerja Lingkungan terhadap Pengungkapan Lingkungan (Studi Empiris pada Perusahaan Manufaktur dan Tambang yang Terdaftar pada Bursa Efek Indonesia (BEI) dan Termasuk dalam PROPER Tahun 2009-2011). Diponegoro Journal of Accounting. 2 (3): 201-210.

Rehman, Z.U. \& M.K. bin Dost. (2013). Conceptualizing Gren Purchase Intention in Emerging Market. The 2013 WEI International Academic Conference Proceedings: 99-120.

Rouf, A. (2011). Corporate characteristics, governance attributes and the extent of voluntary disclosure in Bangladesh. African Journal of Business Management. Vol.5(19): 7836-7845

Rudito, B. \& M. Famiola. (2007) Etika Bisnis dan Tanggung Jawab Sosial Perusahaan di Indonesia. Edisi 1. Jakarta: Rekayasa Bisnis

Stray, S. (2008). Environmental Reporting: the UK Water and Energy Industries: a Research Note. Journal of Business Ethics, Vol. 80 (4): 697-710.

Sun, Nan, et. al. (2010). Corporate Environmental Disclosure, Corporate Governance and Earnings Management. Managerial Auditing Journal. Vol. 25 (7): 611-620.

Surya, I. \& I. Yustiavandana. (2006). Penerapan Good Corporate Governance: Mengesampingkan Hak-Hak Istimewa Demi Kelangsungan Usaha. Jakarta: Lembaga Kajian Pasar Modal dan Keuangan Fakultas Hukum Universitas Indonesia. 
Wahyuni, S. (2011). Qualitative Research Method: Theory and Practice. Jakarta: Salemba Empat

Wallace, P \& J. Zinkin. (2005). Mastering Business in Asia: Corporate Governance. Singapore: John Wiley \& Sons (Asia) Pte Ltd.

Zikmund. W.G. et. al. (2010). Business Research Methods $8^{\text {th }}$ ed. New Jersey: South Western Cengage Learning. 